\title{
AUTORSKIE PRAWA OSOBISTE W USTAWODAWSTWACH FRANCJI I REPUBLIKI FEDERALNEJ NIEMIEC - ANALIZA PRAWNOPORÓWNAWCZA
}

\section{WPROWADZENIE}

Na gruncie postanowień prawa autorskiego w ustawodawstwach Francji i Niemiec konstrukcyjnie wyróżniamy dwa modele: dualistyczny i monistyczny. Dualistyczny, przyjęty przez normodawstwo francuskie, charakteryzuje się wydzieleniem dwóch autonomicznych praw autorskich - osobistych i majątkowych. Różnice zachodzące między tymi samodzielnymi uprawnieniami dotyczą zwłaszcza czasu trwania i przewidzianych ustawowo środków ochrony oraz zasad określania uprawnionego podmiotu. W ujęciu pluralistycznym zakłada się zatem istnienie wielu dóbr i skorelowanych z nimi odrębnych praw podmiotowych. W przeciwieństwie do porządku francuskiego u podstaw niemieckiego prawa autorskiego znajduje się koncepcja monistyczna, w myśl której uprawnienia twórcy traktowane sa jako jednolite i niezbywalne prawo, służące do ochrony jego interesów zarówno w aspekcie osobistym, jak i majątkowym. Monistyczna konstrukcja praw autorskich przyjmuje istnienie jednego dobra osobistego, które stanowi źródło cząstkowych uprawnień.

Pomimo oczywistych rozbieżności doktrynalnych, analiza komparatystyczna ma na celu zarówno wskazanie zróżnicowanych podstaw prawnych $\mathrm{w}$ danych systemach i odmiennych instytucji jurydycznych, jak i istnienia wspólnych, podstawowych aspektów ochrony w sferze osobistej. Odmienne traktowanie samej konstrukcji praw autorskich w wybranych reżimach nie wpływa na uznaną za wspólny mianownik kwestię twórczego pierwiastka, który ma dominujące znaczenie przy określaniu i wykonywaniu przez upoważniony podmiot uprawnień z tytułu działalności intelektualnej ${ }^{1}$.

${ }^{1}$ A. Lucas, H.-J. Lucas, Traité de la propriété littéraire et artistique, wyd. 2, Paris 2001, s. 13; H. Desbois, Le droit d'auteur en France, wyd. 3, Paris 1978, s. 469; J. Ellis, Copyright Law, Urheberrecht und ihre Harmonisierung in der Europäischer Gemeinschaft, Berlin 1997, s. 378-379. 


\section{PRAWO AUTORSKIE WE FRANCJI}

Niezaprzeczalne oddziaływanie ustawodawstwa francuskiego na kształt europejskiego systemu ochrony praw autorskich odnosi się głównie do problematyki praw osobistych twórców. Przyjęcie na gruncie prawa francuskiego koncepcji dualistycznej przyczyniło się do wykształcenia podstawowych instytucji jurydycznych w odniesieniu do autorskich dóbr osobistych, których podstaw upatruje się $\mathrm{w}$ tradycji idei rewolucji francuskiej i wypowiedziach dziewiętnastowiecznej judykatury ${ }^{2}$. Postulat wysuwany we francuskiej literaturze przedmiotu uznaje niepodzielność osoby twórcy i jego dzieła, co stanowi podstawę jego uprawnień osobistych ${ }^{3}$. Znalazło to odzwierciedlenie w koncepcji personalistycznej (conception personnaliste) ${ }^{4}$, która zakłada, że pojęciem zasadniczym jest utwór powstały w wyniku działalności intelektualnej, kwalifikowanej jako akt twórczy, a będący emanacją osobowości twórcy.

Podstawowa regulacja w dziedzinie praw autorskich jest inkorporowana do obecnie obowiąujacego Kodeksu własności intelektualnej (Code de la propriété intellectuel) $)^{5}$, ustawa z 11 marca $1957 \mathrm{r} .{ }^{6}$ Za podstawę konstrukcji osobistych praw autorskich uznaje się ścisłe powiązanie utworu z twórca, jako emanacja jego unikalnej osobowości ${ }^{7}$. Artykuł L. 111-1 ust. 2 CPI statuuje, że utwór, jako uzewnętrznienie osobowości autora, stanowi urzeczowione przymioty intelektualne i osobiste (attributs d'ordre intellectuel et moral). W myśl przytoczonego przepisu należy odnieść się do kwestii reguł klasyfikacji poszczególnych dóbr niematerialnych jako utworu. Przesłanka twórczości jest zrealizowana wówczas, gdy istnieje subiektywnie nowy wytwór intelektu. Sam jednak twórczy charakter dzieła nie jest wystarczajacy do zakwalifikowania go do kategorii chronionych utworów z tytułu prawa autorskiego. Odpowiednie normy prawne przewiduja uznanie indywidualności dzieła, przez przyjęcie wyróżnika oryginalności, który jednak odnosi się jedynie do zobiektywizowanego określenia powiązania z niepowtarzalna osobowością człowieka, nie przyjmując żadnych kategorii wartościujących $\mathrm{w}$ stosunku do jego walorów artystycznych, moralnych czy intelektualnych ${ }^{8}$. Zgodnie z zasadą zawartą w art. L. 112-1 CPI każdy przedmiot intelektualny, niezależnie od formy wyrażania, wartości czy przeznaczenia, może być uznany za utwór, jeśli tylko jest oryginalny. Kodeks nie wprowadza zatem żadnej

\footnotetext{
2 Cass. 18 floréal an XII, Dictionnaire de l'Académie, Rép. an XII, s. 475.

${ }^{3}$ X. Linant de Bellefonds, Droit d'auteur et droits voisins, wyd. 2, Paris 2002, s. 4.

${ }^{4}$ H. Desbois, op. cit., s. 469; A. Lucas, H.-J. Lucas, op. cit., s. 301.

${ }^{5}$ Loi № 92-597 du $1^{\text {er }}$ juillet 1992 relative au Code de la priopriété intelectuelle (partie législative) (dalej jako: CPI).

${ }^{6}$ Loi No 57-298 du 11 mars 1957 sur la priopriété littéraire et artistique (dalej jako: ustawa z 11 marca 1957 r.).

7 X. Linant de Bellefonds, op. cit., s. 21.

8 Teza wyroku w sprawie Maty c. Mauboussin (Civ. I, 20 marca 2001 r., „Revue Internationale du Droit d'Auteur” 2001, nr 189, s. 347) stwierdza, że dzieło jest oryginalnym wytworem działalności twórczej w myśl CPI, nawet jeżeli odwołuje się do powszechnie wiadomych idei, znanych faktów czy innych elementów uznanych za banalne. Nie można również określać st o p nia oryginalność - jest to kategoria niezmienna.
} 
dodatkowej przesłanki poddania utworu prawu autorskiemu ${ }^{9}$, ważne jest jedynie istnienie faktycznego indywidualnego wkładu.

Kształt CPI powiązany jest z przyjęciem koncepcji wielości praw autorskich - wprowadza podział na uprawnienia o charakterze majątkowym i prawa osobiste przysługujące twórcom. W sferze przyznanych przez legislatora praw niemajątkowych wyróżnione podstawowe uprawnienia to: prawo do poszanowania nazwiska autora i przymiotów osobistych twórcy oraz utworu (art. L. 121-1 CPI). Na mocy norm zawartych w art. L. 111-1 ust. 1 CPI konstrukcja uprawnień osobistych twórców oparta jest na koncepcji praw podmiotowych o skuteczności erga omnes ${ }^{10}$. Ponadto, w odróżnieniu od innych systemów prawnych, pozycja autora została dodatkowo literalnie wzmocniona przez postanowienia przywołanego przepisu - zdanie pierwsze, w myśl którego twórca nabywa wyłączne i absolutne prawo własności intelektualnej (priopriété incorporelle) na podstawie samego aktu twórczego ( $d u$ seul fait de sa création). Tylko osoba fizyczna może być autorem w rozumieniu francuskiej ustawy. Jedynym dopuszczalnym wyjątkiem są dzieła zbiorowe powstałe z inicjatywy osoby prawnej ${ }^{11}$. Regulacja ta miała za cel określenie sytuacji prawnej dla specyficznych utworów, jakimi są słowniki, encyklopedie czy leksykony ${ }^{12}$.

W myśl utrwalonego w doktrynie i orzecznictwie poglądu uprawnienia osobiste zyskują prymat nad majątkowymi, co najdobitniej ujawnia się w sytuacji, gdy nabywca praw majątkowych może być ograniczony w ich wykonaniu przez wzgląd na zapewnienie twórcy jego prerogatyw podmiotowych ${ }^{13}$. Prawa określone przedmiotową ustawą zakładaja, w odniesieniu do dóbr osobistych, atrybut nieprzedawnialności ${ }^{14}$. Powyższa koncepcja została przyjęta jako rezultat ujmowania utworu na podstawie powiąania go z długotrwała projekcją niepowtarzalnej osobowości autora, która znalazła w nim odbicie i przeżywa twórcę ${ }^{15}$. Według dominującego stanowiska przedstawicieli francuskiej nauki prawa nieprzedawnialny charakter praw osobistych jest podstawowym czynnikiem odróżniającym je od uprawnień majątkowych, którym z góry przypisany jest limitowany czas trwania ${ }^{16}$. Podstaw konstrukcji prawnej przytoczonych uprawnień upatruje się w art. L. 121-1 - L. 121-9 CPI. Niekiedy w literaturze przedmiotu wypowiadany jest jednak pogląd, że cecha bezterminowości autorskich dóbr osobistych jest praktycznie niewykonalna, gdyż dochodzi do znacznego osłabienia ochrony po śmierci twórcy. Ponadto wątpliwości budzi zwłaszcza kwestia określenia podmiotu tych praw oraz ich treści ${ }^{17}$. W piśmiennictwie francuskim za konsekwencję niemajątkowego charakteru

\footnotetext{
${ }^{9}$ Cel powstania dzieła, jego postać, jakość, rozmiar i in.

10 Art. L.-111-1 CPI.

11 Treść CPI jedynie na zasadzie fikcji prawnej traktuje osoby prawne jako autorów.

12 Celem powyższej regulacji było przyzwolenie, by osoba prawna faktycznie została uznana za twórcę - zbliżenie do amerykańskiego modelu work for hire.

13 X. Linant de Bellefonds, op. cit., s. 243 i 245.

14 Ibidem, s. 245 i 246.

15 Art. L. 121-1 ust. 3 zd. drugie CPI.

${ }^{16}$ W relacji do majątkowych: X. Linant de Bellefonds, op. cit., s. 246 i 247.

17 Ochrona osobista post mortem auctoris po upływie dwóch, trzech pokoleń jest praktycznie niemożliwa. Por. A. Lucas, H.-J. Lucas, op. cit., s. 306.
} 
praw autorskich przyjmuje się również ich nieprzenoszalność i niemożność całkowitego zrzeczenia się. Redakcja przepisu L. 121-1 CPI przesądza o tym, że twórca nie może wyrzec się przypisanych mu praw osobistych. Jakkolwiek regulacja ta nie ma charakteru bezwzględnego i podlega ograniczeniom w celu ochrony uzasadnionych interesów osób trzecich.

Prawo do autorstwa jawi się jako podstawowy przejaw autorskich praw osobistych. Artykuł L. 121-1 CPI statuuje, że autorowi przysługuje prawo do poszanowania jego nazwiska oraz przymiotów osobistych (,l'auteur jouit du droit au respect de son nom [et] de sa qualité"). Według przedstawicieli nauki prawa zwrot ten można uznać za podstawę wszelkich roszczeń związanych z naruszeniem nazwiska autora, jak również jego reputacji czy honoru ${ }^{18}$. Co więcej, A. Lucas sugeruje, że odwołanie do samych przymiotów autora (qualité) jest charakterystyczne dla francuskiego systemu autorskiego, gdyż w żadnym innym porządku nie podkreśla się literalnie innych cech twórcy poza nazwiskiem. Przytoczone uprawnienie posiada swoją stronę pozytywna - prawo do proklamowania autorstwa przez wskazanie nazwiska autora, oraz negatywna, wyrażona możnością używania oznaczenia przesłaniającego (pseudonimu lub rozpowszechniania dzieła anonimowo). Regulacja dotyczaca kwestii użycia pseudonimu i anonimowości twórcy zawarta jest w przepisie L. 113-6 CPI. Należy podkreślić, że w myśl wskazanego artykułu, twórcom korzystającym z dopuszczenia działalności intelektualnej bez powoływania się na własne nazwisko przysługuje pełnia praw autorskich.

Wskazane normy przewidują możliwość dochodzenia roszczeń w przypadku przywłaszczenia, ale i pominięcia autorstwa. Jednakże wyrażenie pr a w o do poszanowania nazwiska jest definiowane zbyt szeroko i często rodzi liczne wątpliwości, stąd należy odwołać się do wypowiedzi judykatury, które uzupełnia regulacje normatywną. Na kanwie wyroku w przedmiotowej sprawie Sąd Apelacyjny w Paryżu orzekł, że autor może dochodzić swoich praw w przypadku błędnego przyporządkowania utworu do jego nazwiska ${ }^{19}$, z kolei rozstrzygnięcie w sprawie Rachmaninow ${ }^{20}$, dało podstawę do dochodzenia roszczeń o naruszenie prawa do poszanowania nazwiska w przypadku dowodzenia, jakoby nazwisko twórcy bardziej wiązało się z produktami alkoholowymi niż dziełami artystycznymi ${ }^{21}$. Liczne wypowiedzi judykatury uznały za bezprawne nawet domniemanie autorstwa, zakładające błędne przypisanie dzieła twórcy w myśl ustawy z 9 lutego 1895 r. o prawie podstawowym do poszanowania nazwiska ${ }^{22}$. Doktryna prawa, opowiadając się przeciw wszelkim nadużyciom nazwiska określonego autora, wypracowała konstrukcję droit de

18 Ibidem, s. 326-327.

19 CA Paris 1996, „Revue Internationale du Droit d'Auteur” lipiec 1997, s. 321.

20 Paris, 27 październik 1988 r., JCP 1990, s. I 3433.

${ }^{21}$ Chociaż zdarzają się i rozstrzygnięcia, które ograniczają prawo do autorstwa: Sąd Apelacyjny w Paryżu orzekł, że autorowi piosenki użytej w reklamie nie przysługuje prawo do wskazania nazwiska, ponieważ film reklamowy nie zawierał żadnych napisów - CA Paris $4^{\mathrm{e}}$ chambre, 6 marca 1991 r., D. 1992 som. P75.

22 TGI Paris, „Les petites affiches” 1993, nr 150, s. 9; Cass. crim., 27 września 1994 r., JCP 1995 IV 92 i Civ. I, 18 lipca 2000 r., D. 2001, s. 541 - sprawa rzekomego dzieła francuskiego malarza Maurice'a Utrillo. 
non-paternité, ustanawiająca możliwość ochrony przed niepoprawną atrybucją dzieła danemu twórcy ${ }^{23}$.

Kolejnym podstawowym uprawnieniem osobistym jest prawo do upublicznienia utworu (art. L. 121-1 CPI). Jakkolwiek przytoczony przepis odnosi się do problematyki praw osobistych, jego wykonanie rzutuje również na sferę uprawnień majątkowych twórców - decyzja o pierwszym udostępnieniu może ograniczyć czy wręcz zakazać rozpowszechnienia dzieła upoważnionym z tytułu autorskich praw majątkowych ${ }^{24}$. Droit de divulgation zarówno podkreśla więź autora z dziełem, jak i potwierdza koncepcję prymatu praw osobistych w relacji z majątkowymi. Twórca decyduje w pełni subiektywnie, w jakiej formie i czasie dzieło ma zostać przedstawione publiczności, właściciele corporis mechanici zaś są uzależnieni od czytelnej woli upublicznienia autora ${ }^{25}$. W kwestii wykonywania prawa do pierwszego upublicznienia należy przywołać tezę wyroku w sprawie Rouault ${ }^{26}$, w której Sąd Apelacyjny w Paryżu orzekł, że dzieło sztuki do chwili rozpowszechnienia poprzez czytelną wolę twórcy pozostaje wyłączone z obrotu handlowego.

W orzecznictwie francuskim na uwage zasługuje utrwalony pogląd, stanowiący o prawie autora do zwolnienia ze zobowiązań umownych na mocy przytoczonego uprawnienia osobistego ${ }^{27}$. Chociaż w przyjętej linii orzecznictwa kładzie się nacisk na stosowanie ujęcia obiektywnego w ocenie kolidujących interesów twórców i nabywców praw majątkowych, w praktyce częściej dochodzi do rozszerzenia zakresu obrony niż jej zawężenia - o ile nie mówimy o sytuacji nadużyć czy oszustwa ze strony danych podmiotów ${ }^{28}$. Potwierdzeniem tego stanowiska jest wyrok wydany w sprawie Whistler ${ }^{29}$, w którym sąd orzekł, że wskutek umowy dzieło (portret) staje się własnością nabywcy dopiero z chwilą decyzji autora o jego upublicznieniu. Na kanwie tego orzeczenia stwierdzono nawet, że wystawienie dzieła w galerii nie należy koniecznie uznać za faktyczną decyzję o pierwszym udostępnieniu. Ciekawym orzecze-

${ }_{23}$ Sprawa Paul Renoir TGI Paris, 9 maja 1995 r., „Revue Internationale du Droit d'Auteur” maj 1995, s. 323. Większość przedstawicieli francuskiej doktryny (A. Lucas, C. Colombet, H. Desbois) opowiada się za uznaniem błędnej atrybucji utworu za formę naruszenia powszechnych dóbr osobistych. Por. S. Strömholm, Le droit moral de l'auteur, Stockholm 1966, s. 310.

24 Por. C. Colombet, Priopriété littéraire et artistique et droits voisins, wyd. 7, Paris 1994, s.112 - C. Colombet stwierdza, że prawo do upublicznienia jest warunkiem powstania praw majątkowych. W klasycznym wyroku w przedmiotowej sprawie (Orléans, 17 marca 1965 r., JCP 1965, II, 14186), zostało podkreślone nawet odejście od cechy absolutyzmu prawa własności zawartej w art. 2279 francuskiego kodeksu cywilnego w odniesieniu do egzekwowania autorskich praw osobistych.

25 H. Desbois, op. cit., s. 150, przyp. 317.

${ }_{26}$ Paris, 19 marca 1947 r., D. 1949, 20.

27 A. Lucas, Droit d'auteur et numérique, Paris 1998, s. 234.

28 Cass. civ., 14 marca 1900 r., Eden c/Whistler, DP 1900. 497 - mimo że rozważania w zaskarżonym wyroku odnosiły się tylko do kwestii majątkowych, Sąd Kasacyjny sformułował przywołaną zasadę w oparciu o uprawnienia osobiste twórcy. CA Paris, 19 marca 1947 r., D. 1949. 20 - sprawa Rouault.

${ }^{29}$ Cass. civ., 14 marca 1900 r., Eden c/Whistler, DP 190, 497. Jakkolwiek twórca może zostać zmuszony do zwrotu wpłaconej przez kontrahenta zaliczki bądź innych zadośćuczynień materialnych zgodnie z przepisem art. 1142 francuskiego kodeksu cywilnego. 
niem jest również rozstrzygnięcie w sprawie Camoin/Cargo ${ }^{30}$, w której przyznano pisarzowi prawo do zakazu upublicznienia dzieła, wyrzuconego przez twórcę do kosza na śmieci. Po analizie wyników wariantów wykładni, należy stwierdzić, że judykatura przyjęła twierdzenie o stosowaniu prawa do pierwszego upublicznienia w odniesieniu do konkretnej formy - dzieło przeznaczone do nadawania drogą telewizyjną nie może ukazać się w formie książki bez zgody autora, jak również zdjęcia opublikowane w czasopiśmie nie zakładają upowszechnienia w programach telewizyjnych ${ }^{31}$. Potwierdzenie tej normy zostało wyartykułowane w tezie wyroku sprawy Roland Barthes ${ }^{32}$, dotyczacej publikacji części wykładu wygłoszonego przez filozofa w Collège de France. Przedstawiciele francuskiej nauki prawa nie są zgodni co do kwestii jednorazowości omawianego uprawnienia - przeważa jednak pogląd o wyczerpaniu się prawa do upublicznienia po pierwszym przedstawieniu dzieła przez autora publiczności ${ }^{33}$. Stanowisko to zostało podtrzymane przez wypowiedzi judykatury - Sąd Apelacyjny w Paryżu orzekł, że „prawo do upublicznienia dzieła wyczerpuje się poprzez pierwsze zakomunikowanie publiczności”34.

Ostatnim z podstawowych uprawnień osobistych twórców jest prawo do zachowania integralności utworu (droit au respect de l'œuvre). Jego podstawą normatywną jest art. L. 121-1 ust. 1 CPI, z kolei art. L. 132-11 ust. 2 i art. L. 132-22 CPI stanowią jego dopełnienie, ustanawiające sytuację poszczególnych dzieł na określonych polach eksploatacji. Zasada nienaruszalności utworu dąży do wzmocnienia pozycji autora w stosunku do nabywców egzemplarzy dzieł i ochrony dzieła przed bezprawnym zniekształceniem ${ }^{35}$. Uprawnienie to nie ma charakteru bezwzględnego, podlega bowiem rozlicznym ograniczeniom, takim jak korekta błędów ${ }^{36}$, a w przypadku dzieł o charakterze informacyjnym (encyklopedie, podręczniki) - możność wprowadzenia aktualizacji lub uzupełnień ${ }^{37}$. Pomimo przywołanych dopuszczalnych ograniczeń, w systemie francuskim przyjęto najszerszą definicję droit

30 Paris, 17 luty 1988 r., D. 1989, som. 50. Sąd orzekł, że własność literacka i artystyczna daje uprawnionemu prawo, które nie jest związane z jakąkolwiek korzyścia materialna, artyście zaś umożliwia prawo do upubliczniania za życia swoich dzieł w sposób i na warunkach, które uzna za odpowiednie.

31 Paris, 13 luty 1981 r., Cass. civ. 1ère, 5 lipca 1984 r., „Revue Internationale du Droit d'Auteur" kwiecień 1982 r., s. 126.

32 TGI Paris 1̀̀ 20 listopada 1991 r., Légipresse 1992, III, s. 38.

${ }^{33}$ Według P. Sirinellego (P. Sirinelli, Droit moral de l'auter et droit commun des contrats, Paris 2, 1985) uprawnienie to dotyczy każdorazowo upublicznienia w odrębnej formie, czy innym kanałem przekazu, z kolei A. Lucas postuluje wyważenie kwestii wykonywania prawa do upublicznienia podczas nowego rozpowszechnienia w celu niedopuszczenia do naruszenia stosownych praw innych podmiotów.

${ }^{34}$ CA Paris, $4^{\text {ème }}$ ch., sect. A, 14 lutego 2001 r., Gauthier et Terrangle c/Sté France animation $S A$.

35 Wyrok w sprawie Czekajac na Godota Samuela Becketta (TGI Paris, 15 październik 1992 r., Cass. civ. 1ère, 5 lipca 1984 r., „Revue internationale du droit d'auteur” 1993, nr 155, s. 225), w którym zawarto tezę, że ani osoby trzecie, ani sąd nie może orzekać, czym jest istota formy i treści danego utworu - jest to uprawnienie wyłączne twórcy.

${ }^{36}$ Lyon, 12 czerwca 1989 r., D. 1989, IR 234.

37 X. Linant de Bellefonds, op. cit., s. 257. 
au respect de l'œuvre, zapewniającą twórcom ochronę przed jakąkolwiek zmianą czy modyfikacją dzieła (quelle qu'en soit l’importance ${ }^{38}$ ).

Uzupełnieniem przytoczonych wyżej regulacji jest bogate orzecznictwo. Warto przytoczyć tezę wyroku w sprawie Dubuffet ${ }^{39}$ (w kwestii zmiany kompozycji lodówki użytej za podstawę utworu artysty przez jej nabywcę), w której organy sądownicze podtrzymały wyłączną kompetencję twórcy do ustalenia kształtu i formy dzieła, odwołujac się do arbitralnego odczucia artysty - to ono faktycznie wyznacza zakres omawianego uprawnienia. Ponadto na twórcy nie spoczywa obowiązek wskazania powodów, dla których nie uznaje modyfikacji własnego dzieła ${ }^{40}$. Jakkolwiek zauważamy niejednorodny charakter linii wypowiedzi judykatury: w wyroku w sprawie Fresques de Juvisy ${ }^{41}$ powołano się na cechy absolutyzmu prawa własności ${ }^{42}$, stwierdzając, że nabywcy przysługuje prawo do dysponowania dziełem, w tym do jego unicestwienia. Późniejsze orzecznictwo odstapiło od powyższego rozstrzygnięcia, przyjmując tezę, że akt zniszczenia dzieła stanowi najwyższy wyraz braku poszanowania osobowości autora, pojmowanej jako więź między twórcą a wytworem intelektualnym. Organy sądownicze odwołują się przede wszystkim do wyważenia kwestii, czy dany utwór przeznaczony był tylko do użytku prywatnego, czy też stanowił dobro wystawiane dla szerszego grona odbiorców. W sprawie Scrive ${ }^{43}$ Sąd Apelacyjny w Paryżu opowiedział się przeciw usunięciu rzeźby z centrum handlowego, ponieważ przeznaczona było do odbioru w miejscu publicznym, zatem nie istniały okoliczności usprawiedliwiające wykonanie jedynie subiektywnej woli właściciela. Z kolei w myśl wyroku wydanego w sprawie Parc de Grenoble A4 $^{4}$ dopuszczalne jest usunięcie dzieła przez wzgląd na bezpieczeństwo publiczne ${ }^{45}$.

\section{PRAWO AUTORSKIE W NIEMCZECH}

Zasadniczym źródłem normatywnym dla ochrony praw twórców jest niemiecka ustawa autorska Gesetz über Urheberrecht und verwandte Schutzrechte (Urheberrechtsgesetz) ${ }^{46}$. Ze względu na konstrukcję i katalog autorskich dóbr i uprawnień znaczący jest $§ 11$ zd. pierwsze UrhG, zgodnie z którym

38 Cass. civ. $1^{\text {ère }}, 17$ grudnia $1991 \mathrm{r}$.

39 Cass. civ. 1ère, 6 lipca 1965, nr 62-3.544 1965, „Revue Internationale du Droit d'Auteur” lipiec 1965, s. 221. Klasyczny wyrok, który przedstawiciele sztuki nowoczesnej uznali za faktyczne objęcie ustawą autorską również dzieł o kwestionowanej do tej pory wartości artystycznej.

40 TGI Paris 3 è, 15 października 1992 r., „Revue Internationale du Droit d’Auteur” 1995, nr 155 , s. 255.

${ }^{41}$ CA Paris, 27 kwietnia 1934 r., DH 1934, s. 385.

42 Art. 544 francuskiego kodeksu cywilnego.

${ }^{43}$ CA Paris, $25^{\mathrm{e}}$ ch, 10 lipca 1975 r., „Revue Internationale du Droit d'Auteur” styczeń 1977, s. 118 .

${ }_{44}$ T. adm. Grenoble, 18 lutego 1976 r., „Revue Internationale du Droit d'Auteur” styczeń 1977, nr 91, s. 116.

${ }^{45}$ Cass. civ. I, 7 stycznia 1992 r., D. 1993, 522.

${ }^{46}$ Gesetz über Urheberrecht und verwandte Schutzrechte (Urheberrechtsgesetz) z 9 września 1965 r. (dalej jako: UrhG). 
w niemieckim systemie prawo autorskie chroni twórcę w zakresie jego duchowych i osobistych relacji z dziełem, jak również w zakresie korzystania z utworu, jest zatem związane z ochroną interesów twórców zarówno w sferze osobistej, jak i majątkowej. Powyższa regulacja statuuje tzw. system monistyczny, w którym poszczególne przymioty osobiste są skonkretyzowanymi postaciami ogólnego prawa osobistości ${ }^{47}$. W teorii monistycznej, w odróżnieniu od koncepcji dualistycznej, przyjmuje się nierozdzielność praw autorskich ${ }^{48}$ przez połaczenie praw osobistych (Persönlichkeitsrechte) i majątkowych (Verwertungsrechte), tworzacych tzw. untrennbare Einheit - niepodzielną całość ${ }^{49}$. Ogólne prawo autorskie stanowi zatem źródło odpowiednich uprawnień czasstkowych twórców ${ }^{50}$. Ustanowienie prawa autorskiego odnosi się do konkretnego procesu rozumowego, jako rezultatu działalności twórczej, spełniającego przesłankę indywidualności. Należy podkreślić, że o ile w reżimie francuskim do objęcia ustawowa ochroną utwór powinien posiadać cechę oryginalności, o tyle w niemieckiej literaturze przedmiotu akt kreacji przejawia się w zindywidualizow an ej formie i treści.

Na gruncie niemieckiej regulacji twórca - osoba fizyczna - zawsze nabywa prawa do utworu w sposób pierwotny. Na szczególną uwagę zasługuje dorobek doktryny niemieckiej, w którym zasada prawa do atrybucji utworu (Schöpferprinzip) przejawia się w analogiczny sposób również w stosunku do utworów pracowniczych. Jest to możliwie najszersza formuła przyznania prawa do autorstwa, pozostająca w zupełnej opozycji do państw tradycji common law.

Prawo autorskie, ustanowione jako prawo nieprzenoszalne, w myśl przepisu $§ 29 \mathrm{zd}$. drugie UrhG, zawsze powstaje na rzecz twórcy. Warto pokreślić fakt, że w regulacji niemieckiej autor nie może przenieść uprawnień mu należnych na inny podmiot przez cesję, a jedynie udostępnić częściową eksploatację na określonych polach. Ustanowienie prawa na rzecz osób trzecich w niemieckim systemie autorskoprawnym doprowadziło do wprowadzenia odrębnego terminu na określenie praw podmiotów upoważnionych z tytułu praw majątkowych w sposób wtórny - Nutzungsrechte ${ }^{51}$.

Podstawą prawnej ochrony interesów twórców jest istnienie więzi uczuciowej $^{52}$ - viniculum spirituale, ujawniającej się w zachowaniu odpowiednich

${ }^{47} \mathrm{~W}$ literaturze przedmiotu wyróżnia się zasadniczo dwa rodzaje monizmu: monizm powiązany z osobą twórcy, który zakłada brak możliwości zrzeczenia się z przysługujących autorom uprawnień, nawet po udzieleniu licencji (po cesji praw majątkowych) - monizm personalny ( $m o$ nisme personnaliste - personalistischen Monismus) oraz teorię uznająca autonomiczne wykorzystanie utworu w obrocie handlowym i ograniczająca środki ochrony jedynie do udzielenia ochrony deliktowej stosownym interesom (monizm realistyczny - monisme réaliste - realistisch Monismus).

${ }^{48}$ Por. M. Lijowska, Koncepcja ogólnego prawa osobistości $w$ niemieckim i polskim prawie cywilnym, „Kwartalnik Prawa Prywatnego” 2001, nr 4, s. 758.

${ }^{49}$ A. Dietz, The Moral Rights of the Author: Moral Rights and the Civil Law Countries, „Columbia University School of Law and Volunteer Lawyers for the Arts - Journal of Law \& the Arts" 19, 1995, s. 205.

${ }^{50}$ E. Ulmer, Urheber- und Verlagsrecht, wyd. 3, Berlin 1980, s. 116.

${ }^{51}$ Przytoczona kategoria pojęciowa określa czynność konstytutywnego nabycia prawa do korzystania z dzieła przez osoby trzecie, na podstawie odpowiedniego aktu (§ 31 UrhG).

${ }^{52} \mathrm{M}$. Fröhlich, Zentrale Institutionen des deutschen Urheberrechts und des französischen 
relacji autora $\mathrm{z}$ dziełem, w aspekcie intelektualnym i emocjonalnym, przy jednoczesnej dbałości o interesy majątkowe autorów. Pomimo splatania się obu kategorii uprawnień - majątkowych i osobistych - możemy zauważyć próby ich rozróżnienia w niemieckiej doktrynie prawniczej. W literaturze przedmiotu przyjęto definicję praw autorskich w szerszym i węższym znaczeniu ${ }^{53}$, odpowiadajacym częściowo podziałowi na uprawnienia majątkowe i osobiste w systemach dualistycznych. Prawo do autorstwa, do upublicznienia i do integralności utworu, zawarte w § 12-14 UrhG, stanowią kategorię uprawnień autorskich sensu stricto, z kolei w kontekście szerszym przejawia się ochrona praw majątkowych.

Zasadniczą różnicą w stosunku do systemu dualistycznego (zwłaszcza $\mathrm{w}$ formie przyjętej przez doktrynę francuska) jest wprowadzenie jednolitego czasu trwania dla praw osobistych i majątkowych.

W niemieckiej doktrynie wskazano na prawo do autorstwa i do atrybucji utworu jako podstawę wieloaspektowej ochrony praw autorskich (Recht auf Anerkennung der Urheberschaft ${ }^{54}$. W myśl § 13 zdanie pierwsze UrhG twórcy przysługuje uprawnienie do uznania autorstwa własnego utworu. W piśmiennictwie niemieckim pojawia się ujmowanie tego prawa w podwójnym znaczeniu - jako poszanowanie autorstwa i dopiero w ujęciu szerszym - jako szereg uprawnień dotyczących już właściwego sposobu atrybucji utworu. Pogląd przyjęty przez przedstawicieli niemieckiej nauki prawa podkreśla swobodę autora do określenia i wyboru znaku identyfikacyjnego - utwór może być rozpowszechniany pod nazwiskiem twórcy, pod pseudonimem bądź anonimowo ${ }^{55}$.

Na uwagę zasługuje postulowane w doktrynie i judykaturze twierdzenie, że wskazanie autora musi nastapić niezależnie od sposobu czy pola eksploatacji dzieła ${ }^{56}$. Liczne wypowiedzi judykatury potwierdziły wysuwaną tezę. Przyjęta linię orzecznictwa podtrzymał Sąd Krajowy w Monachium, który w sprawie nieprawidłowego zestawienia zdjęć orzekł, że nieprecyzyjne i niejednoznaczne wskazanie twórcy jest naruszeniem prawa do autorstwa dzieła ${ }^{57}$. Ponadto na kanwie przytoczonego wyroku Sąd Krajowy wytyczył granicę stosowania zwyczajów przy eksploatacji dóbr intelektualnych w praktyce zawodowej ${ }^{58}$. Podobnie do rozwiązań przyjętych w prawodawstwie francuskim, proklamowanie autorstwa nie odnosi się tylko do dzieł realnie komunikowanych publiczności, lecz również do innych sposobów przedstawienia utworu, nieodnoszących się

Droit d'auteur auf dem Prüfstand Netzwerke, Saarbrücker Studien zum Privat-Wirtschaftsrecht, P. Lang (red.), t. 23, Berlin-Bern 2001, s. 66.

${ }^{53}$ W. Bullinger, w: A. A. Wandtke, W. Bullinger (red.), Praxiskommentar zur Urheberrecht, München 2002, s. 137, nb. 4; G. Schulze, w: T. Dreier, G. Schulze, Urheberrechtsgesetz. Urheberrechtswahrnehmungsgesetz. Kunsturhebergesetz. Kommentar, wyd. 2, München 2004, s. 178.

${ }^{54}$ BGH, GRUR 1995, 671, 672.

${ }^{55}$ Prawo to należy rozumieć w sposób ścisły - UrhG nie zakłada możliwości odniesienia wskazanego uprawnienia do takich instytucji, jak fundacje, muzea czy szkoły wyższe.

${ }_{56}$ M. Rehbinder, Urheberrecht. Ein Studienbuch, München 1998, s. 171; BGH, GRUR 1963,40,43 - Straßen - gestern und morgen; BGH, GRUR 1972, 713, 714 - Im Rhythmus der Jahrhunderte.

${ }^{57}$ LG München, ZUM 1995, 57, 58.

${ }^{58}$ Sąd stwierdził, że „zwyczaj, który jest sprzeczny z normami prawnymi [...], nie zasługuje na prawne uznanie". 
do jego rzeczywistej materialnej formy ${ }^{59}$. Funkcji identyfikacyjnej omawianego uprawnienia niemiecka ustawa autorska przypisuje doniosłe skutki prawne: UrhG chroni twórców przed przywłaszczeniem wytworu intelektualnego przez osoby nieuprawnione ( $\mathrm{w}$ formie plagiatu, imitacji, bądź błędnego przypisania autorstwa), § 10 UrhG stanowi, że ujawnienie nazwiska lub znaku przesłaniającego na danym dziele i jego upublicznienie rodzą domniemanie autorstwa ${ }^{60}$, w myśl zaś § 39 UrhG sposób oznakowania utworu zależy wyłącznie od woli autora i nie podlega zmianom i przekształceniom bez jego zgody. $\mathrm{Na}$ mocy norm zawartych w $\S 63$ ust. 1 UrhG podczas eksploatacji dzieł w ramach dozwolonego użytku również należy podać osobę twórcy. Zgodnie z przyjęta praktyką prawa, uprawnienie do określenia autorstwa przysługuje także każdemu z autorów dzieła zbiorowego.

Podstawowa kategoria przyznania prawa do identyfikacji osoby twórcy jest autonomiczny, oryginalny i zauważalny wkład w stworzenie danego dobra niematerialnego, nie uwzględnia ona przy tym nakładu pracy czy czasu poświęconego na wykonanie dzieła ${ }^{61}$. Niemiecka doktryna wykształciła zasadę ograniczonego wpływu nakładu twórczego na moc roszczenia twórcy - nazwana za A. Elsterem - kleine Münze $e^{62}$. Zaobserwować zatem można tendencję do przyznania autorskoprawnej ochrony wytworom intelektualnym, które nie posiadają cech indywidualnej twórczości w powszechnie przyjętym rozumieniu tej przesłanki. Wyraża się to w stosowaniu zdecydowanie łagodniejszych kryteriów w odniesieniu do utworów granicznych, w których aprobuje się nawet minimalny stopień twórczości. Zgodnie z przyjętym w judykaturze niemieckiej twierdzeniem wymagany do uzyskania ochrony twórczy wkład kategoryzowany jakościowo lub ilościowo jest bardzo niski ${ }^{63}$. Wypracowanie instytucji kleine Münze na gruncie prawa niemieckiego ułatwia wyznaczenie minimalnego przejawu indywidualnego ujęcia w utworze, w odróżnieniu od porządku francuskiego, w którym brak ugruntowanego stanowiska w tej kwestii. Na gruncie niemieckiej ustawy autorskiej wprowadzono dwa zasadnicze wyjątki stosowane do ograniczenia prawa do autorstwa - odstępstwa od dowolności oznakowania mogą być przyjęte w drodze umowy bądź przyjętej praktyki $^{64}$.

${ }^{59}$ G. Schulze, w: T. Dreier, G. Schulze, op. cit., s. 191-192. Por. W. Bullinger, w: A. A. Wandtke, W. Bullinger (red.), op. cit., s. 154, nb. 7.

${ }^{60} \mathrm{~W}$ sprawie Biblioteki Państwowej w Berlinie (Staatsbibliothek zu Berlin) Trybunał Federalny orzekł, że oznaczenie autora planu architektonicznego budynku nie ustanawia domniemania autorstwa samego budynku, a jedynie planu (BGH, 14 listopada 2002 r., I ZR 199/00 - Staatsbibliothek).

${ }^{61}$ OLG Frankfurt, OLGZ 107, 16 - Taschenbuch für Wehrfragen; BGH, GRUR 1978, 360, 362 - Hegel-Archiv.

62 Od tezy A. Elstera: „ob es große oder kleine Münze ist”. Określenie kleine Münze podaję za G. Schulzem, który twierdzi, że w literaturze zostało ono po raz pierwszy użyte przez A. Elstera w latach dwudziestych XX w. Rozpatrując konieczny wkład, B. Kaplan (An Unhurried View of Copyright, New York 1966, s. 46) także odwołał się do metafory drobnych monet: twórca musi zdeponować w pudełku jeden grosz, aby znaleźć ochronę w myśl przedmiotowej ustawy.

63 OLG Nürnberg, GRUR 2002 607, 608 - Stufenaufklärung nach Weissauer.

64 Biorąc pod uwagę naturę dzieła, odstapiono od zamieszczania nazwisk czy innych oznaczeń autora np. przy produkcji wzorów użytkowych. 
Należy podkreślić fakt, że zgodnie z niemiecką ustawą autorską współtwórca nie może być osoba prawna. Nie ma zatem podstawy do działań podmiotu niebędącego osobą fizyczna, mających na celu wystapienie z żądaniem wykonania praw autorskich, co jest dopuszczalne na gruncie prawa francuskiego. W niemieckim reżimie autorskoprawnym została zagwarantowana możliwość zaniechania oznaczania cudzego dzieła nazwiskiem osoby, która nie jest twórcą utworu - Recht auf Nichturheberschaft (droit de non-paternitê). Jednak dominująca linia orzecznictwa odmawia obrony przed błędna atrybucja utworu - w klasycznym wyroku w sprawie Cosima Wagner ${ }^{65}$ oddalono roszczenia spadkobierców o naruszenie dóbr osobistych zmarłego kompozytora i nie dostrzeżono możliwości ich obrony po śmierci dysponenta prawa. Rozstrzygnięcie to zostało poddane krytyce, chociaż postulat przyznania ochrony praw osobistości po śmierci danego podmiotu jest uznawany za dyskusyjny przez współczesne orzecznictwo. Jakkolwiek praktyka dostarcza również przykładów odmiennych rozstrzygnięć - Trybunał Federalny w sprawie Emil Nolde $e^{66}$ orzekł, że doszło do naruszenia dóbr osobistych zmarłego autora, odwołując się do ochrony ogólnego prawa osobistości post mortem zawartego w art. 1 ust. 1 niemieckiej Ustawy zasadniczej67, w myśl której godność jako prawo podstawowe człowieka jest nienaruszalna także po jego śmierci.

Kolejnym aspektem prawnej ochrony interesów osobistych twórców jest prawo do upublicznienia dzieła (Veröffentlichungsrecht). Zgodnie z założeniami określonymi w $\S 12$ ust. 1 UrhG autorowi przysługuje uprawnienie do decydowania, czy i w jakiej formie jego dzieło ma być udostępnione publiczności ${ }^{68}$. Prawo do upublicznienia ma swoją stronę: negatywną - autor może zdecydować o nierozpowszechnianiu utworu, oraz pozytywna - wyrażoną wyłącznym uprawnieniem do określenia kształtu i czasu, w którym zostanie on zaprezentowany publiczności ${ }^{69}$. Pomimo odmiennych interpretacji większość przedstawicieli niemieckiego piśmiennictwa dostrzega konieczność przyjęcia poglądu o wyczerpaniu analizowanego prawa wskutek pierwszego upublicznienia utworu ${ }^{70}$. Istotne znaczenie - wobec nieostrych norm ustawowych pełnią wypowiedzi judykatury. Należy przytoczyć rozstrzygnięcia w przedmiotowych sprawach: w orzeczeniu Totenmaske ${ }^{71}$, stwierdzono, że prawo do pierwszego upublicznienia odnosi się do dzieła w konkretnej formie i nie dotyczy rozpowszechniania gipsowego odlewu oryginału, z kolei w kwestii modyfikacji dzieł, w myśl stanowiska utrwalonego w doktrynie, wyczerpanie prawa

${ }^{65}$ BGH, GRUR 1955, 201, 203 - Cosima Wagner. Spadkobiercy kompozytora wystapili o wstrzymanie wydawania jego prywatnej korespondencji. Sąd Najwyższy Rzeszy nie uznał listów za przedmiot objęty ochroną w myśl ówczesnej ustawy autorskiej (z 1870 r.) oraz postulował wygaśnięcie prawa osobistości wraz ze śmiercia osoby.

${ }_{66}^{6}$ BGH, GRUR 1995, 668 - Emil Nolde.

${ }^{67}$ Grundgesetz für die Bundesrepublik Deutschland z 23 maja 1949 r.

${ }^{68}$ Dopełnieniem regulacji zawartej w $§ 12$ UrhG jest treść $§ 6$ UrhG, który ustanawia prawo autora do decydowania o określeniu momentu udostępnienia utworu publiczności.

${ }^{69}$ Ph. Möhring, K. Nicolini, Urheberrechtsgesetz Kommentar, wyd. 2, München 2000, § 12 Rn. 2.

${ }^{70}$ Wyczerpanie prawa postulowali zwłaszcza: G. Schulze, w: T. Dreier, G. Schulze, op. cit., s. 185; A. A. Wandke, W. Bullinger (red.), op. cit., § 12, pkt 9.

${ }^{71}$ KG, GRUR 1981, 742, 443 - Totenmaske. 
do pierwszego upublicznienia zawsze dotyczy określonego sposobu przekazu ${ }^{72}$ (np. spisanie wygłoszonego wykładu wciąż podlega przyzwoleniu autora na udostępnienie $\mathrm{w}$ innej formie $\mathrm{e}^{73}$, wystawienie dzieła $\mathrm{w}$ galerii zaś nie pozwala na upowszechnienie go przez kanał telewizyjny ${ }^{74}$ ). Uprawnienie to jednak nie ma charakteru absolutnego i podlega restrykcjom, przez wzgląd na wymóg zapewnienia słusznej ochrony osobom trzecim lub zapewnienie prawa do informacji czy swobody wypowiedzi ${ }^{75}$. Jakkolwiek na gruncie niemieckiej ustawy autorskiej twórcy nie uzyskali możliwości powołania się na przytoczone uprawnienie osobiste w celu uniknięcia zobowiązań umownych. Przez wzgląd na przyjętą koncepcję jedności praw prerogatywy osobiste (Veröffentlichung) są ściśle powiązane z prawem do eksploatacji dzieła (Verbreitung) - dopuszczalne są zatem przypadki upublicznienia dzieła przez nabywcę praw majątkowych pomimo sprzeciwu autora ${ }^{76}$.

Wykonywanie prawa do upublicznienia utworu powiązane jest z kolejnym uprawnieniem dotyczącym sytuacji prawnoosobistej twórców - prawem do zachowania integralności utworu (Werkschutzrecht). Warto zaznaczyć istniejące różnice w konstrukcji powyższego uprawnienia w teorii monistycznej i dualistycznej - doktryna i judykatura niemiecka skłania się ku koncepcji obiektywnej, zakładając wyważenie skutków modyfikacji utworu dla istoty jego treści, z kolei w systemie francuskim dominuje ujęcie subiektywne, odrzucające jakąkolwiek ingerencję w substancję utworu ${ }^{77}$. Szczegółowa regulacja w systemie niemieckim zawarta jest $§ 14$ UrhG i statuuje, że autor może zakazać wprowadzania zmian i zniekształcania swojego dzieła. Ponadto prawo do zachowania nienaruszonej formy utworu wyrażone zostało w przepisie $\S 39$ ust. 1 UrhG, zgodnie z którym nabywca praw majątkowych nie może w utworze, tytule czy oznaczeniu autorstwa wprowadzać zmian bez zgody autora. Jakkolwiek regulacja zawarta w ustępie drugim osłabia silną zasadę ustępu pierwszego, twórca bowiem zmuszony jest do przyjęcia zmian przez wzgląd na dobre obyczaje. W literaturze przedmiotu i praktyce prawa powszechnie przyjęto rozróżnienie zniekształcenia i modyfikacji dzieła ${ }^{78}$. Należy dokonać oceny stanu faktycznego dzieła po ingerencji, odpowiadając na dwa podstawowe pytania: czy doszło do uszkodzenia substancji utworu i czy tym samym zostały naruszone stosowne interesy twórcy - persönlichen Interessen. Negatywna odpowiedź w obu przypadkach zakłada brak szkody dla istoty dzieła, w przeciwnym razie - jest

${ }^{72}$ BGH 17 kwiecień 1986.

${ }^{73}$ G. Schulze, w: T. Dreier, G. Schulze, op. cit., s. 185.

${ }^{74} \mathrm{Ph}$. Möhring, K. Nicolini, op. cit., § 12.

${ }^{75} \S 45$ UrhG zezwala na upowszechnienie i zwielokrotnianie utworów w przypadku dochodzenia roszczeń przed organami wymiaru sprawiedliwości i organami władzy publicznej; wypowiedzi judykatury dopuściły nawet użycie dzieł niepublikowanych (OLG Frankfurt, ZUM - RD 1999, 379, 383.)

${ }^{76}$ A. Dietz, op. cit., s. 168,60

77 D. Lipszyc, Copyright and Neighbouring Rights, Paris 1999, s. 158.

${ }^{78}$ Zob.: M. Salokannel, A. Strowel, E. Derclaye, Study Contract Concerning Moral Rights in the Context of the Exploitation of Works through Digital Technology: Final Report, Contract Study, $\mathrm{n}^{\circ}$ ETD/99/B5-3000/E28, April 2000, s. 56-70, http://ec.europa.eu/internal-market/copyright/docs/ studies/etd1999b53000e28_en.pdf (dostęp: 14.04.2014). 
to podstawa dochodzenia roszczeń przez autorów ${ }^{79}$. W myśl $\S 39$ ust. 2 twórcy nie przysługuje uprawnienie do zachowania nadanej przez niego formy dzieła, jeżeli przypadki ingerencji są zasadne. Odmiennie traktowana jest, w odniesieniu do systemu francuskiego, także kwestia zniszczenia dzieła. Autor nie może przeciwstawić się unicestwieniu dzieła przez jego nabywcę ${ }^{80}$. Tylko w szczególnych przypadkach możemy rozpatrywać zniszczenie egzemplarza utworu jako nadużycie prawa własności.

\title{
IV. WNIOSKI
}

Koncepcja autorskich praw osobistych bez wątpienia wywodzi się z kontynentalnej tradycji prawnej. Omówienie problematyki droit moral w reprezentatywnych reżimach poświęcone było realizacji poszczególnych dóbr osobistych w ustawodawstwie i praktyce prawa danych państw. Podsumowując, można zauważyć, że konstrukcyjnie jedynie francuskie określenie droit d'auteur w pełni wyraża istotę osobistego charakteru autorskich uprawnień i łączy je ze specyfika kontynentalnego systemu autorskoprawnego, zorientowanego na ochronę interesów samego twórcy i jego więzi z dziełem.

mgr Teodora Konach

Uniwersytet Jagielloński

teodora.konach@uj.edu.pl

\section{AUTHOR'S MORAL RIGHTS IN FRENCH AND GERMAN LEGISLATION \\ - COMPARATIVE APPROACH}

Sum mary

\begin{abstract}
The doctrine of droit moral, one of the most controversial issues in copyright law, has always been considered a matter where a wider international consensus is impossible due to the traditional dichotomy between common law philosophies and authors' rights available in continental civil law systems. However, one of the most noteworthy developments in international copyright law over the past twenty years has been the adoption of statutory protection of moral rights regimes in a number of countries representing the common law tradition. The purpose of this study is to demonstrate that concepts of moral rights in continental law states also differ in structure and provide different means of protection. The article explains the content and characteristics of moral rights, and assesses the most important aspects of French and German national legislations in this area.
\end{abstract}

\footnotetext{
${ }^{79}$ Ciekawą sprawą były roszczenie o naruszenie integralności dzieła grupy muzyków, których utwory wykorzystane zostały przez organizacje neonazistowskie - OLG Frankfurt am Main, GRUR 1995, 215.

${ }^{80}$ RGZ 79, 397, 401 - Felseneiland mit Sirenen. Pierwsze orzeczenie, które przyznało twórcy prawa osobiste w systemie niemieckim.
} 
Copyright of Journal of Law, Economics and Sociology is the property of Faculty of Law and Administration of Adam Mickiewicz University in Poznan and its content may not be copied or emailed to multiple sites or posted to a listserv without the copyright holder's express written permission. However, users may print, download, or email articles for individual use.

Właścicielem praw autorskich do „Ruchu Prawniczego, Ekonomicznego i Socjologicznego” jest Wydział Prawa i Administracji Uniwersytetu im. Adama Mickiewicza w Poznaniu. Zawartość czasopisma nie może być kopiowana, przesyłana do innych stron internetowych bądź zamieszczana na blogach bez pisemnej zgody wydawcy. Niemniej artykuły można drukować, kopiować lub przesyłać w formie elektronicznej na własny użytek. 